Journal of Chromatography, 375 (1986) 1-9

Biomedical Applications

Elsevier Science Publishers B V, Amsterdam - Printed in The Netherlands

CHROMBIO 2890

\title{
SIMULTANEOUS DETERMINATION OF THYMINE AND 5-BROMOURACIL IN DNA HYDROLYSATES USING GAS CHROMATOGR APHY-MASS SPECTROMETRY WITH SELECTED-ION MONITORING
}

\section{PHILIP L STETSON* and JONATHAN MAYBAUM}

Upjohn Center for Clinical Pharmacology, University of Michigan, Ann Arbor, MI 48109 (USA)

UMESH A SHUKLA

College of Pharmacy, University of Michigan, Ann Arbor, MI 48109 (US A)

and

\section{WILLIAM D ENSMINGER}

Departments of Pharmacology and Internal Medicine, University of Michigan, Ann Arbor, MI 48109 (USA)

(First received June 19th, 1985, revised manuscrupt recelved September 18th, 1985)

\section{SUMMARY}

The gas chromatographic-mass spectrometric method using selected-1on monitoring (GC-MS-SIM) described here quantitatively determines the amount of DNA thymine replacement by 5-bromouracil (BU) after exposure to 5-bromo-2'-deoxyuridine (BUDR) in as few as $10^{5}$ cells DNA is extracted, enzymatically hydrolyzed, the nucleic acid bases (with added internal standards, 5-iodouracil and 5-chlorouracil) are extracted into ethyl acetate, concentrated and derivatized with bis(trimethylsilyl)trifluoroacetamide Thymine and BU are then quantitated by GC-MS-SM Response is linear to thymine over the range of $100-2000 \mathrm{ng}$ per sample and BU of $13-52 \mathrm{ng}$ per sample with a coefficient of variation of less than $10 \%$ and an accuracy for seeded samples within $8 \%$ of theoretical value With V79 cells in culture, exposure to increasing BUDR concentrations $(003-10 \mu M)$ results in increasing thymine substitution by $B U$ over a range of $1-28 \%$ Other important applications of this technique are mentioned 


\section{INTRODUCTION}

5-Bromo-2'-deoxyuridine (BUDR) is an analogue of thymidine and is incorporated solely into the DNA of replicating cells [1, 2]. As a result of this substitution, the effected cells become sensitized to toxic effects of ultraviolet [3] and X-irradiation [4]. This radiosensitization of cells induced by exposure to BUDR has been shown to be directly related to the amount of DNA thymine replaced by 5-bromouracil (BU), and with sufficient incorporation radiation sensitivity can be increased from two- to three-fold [4-6]

Quantitation of DNA thymine replacement by BU using high-performance liquid chromatography (HPLC) [7], $\mathrm{CsCl}-\mathrm{Cs}_{2} \mathrm{SO}_{4}$ isopycn1c gradients [3] and monoclonal antibody with fluorescence microscopy and fluorescence activated cell sorting techniques $[8,9]$ has been reported The HPLC method lacks sensitivity (requires $10^{7}$ cells), the isopycnic gradient technique lacks both sensitivity and precision, and it has not been adequately demonstrated that the monoclonal antibody procedures give a quantitative measure of the replacement of DNA thymine by $\mathrm{BU}$ over a broad range of values [8, 9] .

Presented here is a gas chromatographic-mass spectrometric method using selected-ion monitoring (GC-MS-SIM) which quantitatively determines the amount of DNA thymine replacement by BU in as few as $10^{5}$ cells.

\section{EXPERIMENTAL}

\section{Reagents}

The reagents and suppliers were as follows Ethyl acetate and methanol (Burdick \& Jackson Labs., Muskegon, MI, U S A ), monobasic ammonium phosphate (J.T Baker, Philhpsburg, NJ, U S A.), ammonium sulfate (Mallinckrodt, St Lous, MO, U S.A ); BUDR, thymine, 5-chlorouracil (CU), BU, 5-1odouracl (IU), DNAse I, phosphodiesterase, alkalıne phosphatase, and thymıdine phosphorylase (Sigma, St. Louıs, MO, U S A.), bis(trimethylsılyl)trifluoroacetamide (BSTFA) (Pierce, Rockford, IL, U S A ).

\section{Stock solutions}

Thymine solution $(0.1 \mathrm{mg} / \mathrm{ml}$ in methanol $)$, BU solution $(0.13 \mathrm{mg} / \mathrm{ml}$ in methanol), CU solution (01 $\mathrm{mg} / \mathrm{ml}$ in methanol) and $I U$ solution $(01 \mathrm{mg} / \mathrm{ml} \mathrm{in}$ methanol) were prepared and stored at $-20^{\circ} \mathbf{C}$. Saturated ammonium sulfate solution was prepared and stored at room temperature.

\section{Standards}

The BU stock solution was diluted 1.100 with water to yleld the BU standard solution $(1.3 \mu \mathrm{g} / \mathrm{ml} \mathrm{BU})$ The IU stock solution was diluted with water to yield the IU standard solution containing $50 \mu \mathrm{g} / \mathrm{ml}$ IU. The thymine and CU stock solutions were used directly as standard solutions.

Quality-control samples at three BU·thymine concentrations (2 6 200, $104: 1000$ and $20.8 \cdot 1500 \mathrm{ng}$ BU.thymine per $0.10 \mathrm{ml}$ ) were prepared by spiking water with the appropriate volumes of the BU and thymine standard solutions. After mixing, 0.1-ml aliquots were transferred to glass tubes, tightly capped and stored frozen at $-30^{\circ} \mathrm{C}$. Two quality-control samples of each concentration were included with every group of experimental samples to be analyzed. 


\section{Chromatographic conditions}

A Hewlett-Packard 5987 A gas chromatograph-mass spectrometer equipped with a $25 \mathrm{~m} \times 0.32 \mathrm{~mm} \mathrm{I} \mathrm{D}$, fused-silica, capllary column (cross-linked $5 \%$ phenylmethylsilicone, $0.52 \mu \mathrm{m}$ film thickness) was used in these determinations. The HP 5880 gas chromatograph oven temperature was programmed to hold at $100^{\circ} \mathrm{C}$ for $2 \mathrm{~mm}$, then increased at $15^{\circ} \mathrm{C} / \mathrm{mm}$ to $300^{\circ} \mathrm{C}$ The gas chromatograph injection port temperature was $250^{\circ} \mathrm{C}$, the gas chromatographmass spectrometer interface heaters were set to $275^{\circ} \mathrm{C}$ and the mass spectrometer ion source temperature was $200^{\circ} \mathrm{C}$ The mass spectrometer was run in the electron-impact (EI) mode, electron energy of $70 \mathrm{eV}$ and a multiplier voltage of $2200 \mathrm{~V}$ SIM at the following $\mathrm{m} / z$ positive lons was used to detect and quantitate the thymine and $\mathrm{BU}$ levels thymine, $m / z 271, \mathrm{CU}, m / z 276$, $\mathrm{BU}, m / z 319$ and 321 , and IU, $m / z 367$.

\section{Sample preparation}

For analysis of DNA thymine replacement by BU, cell pellets were lysed and DNA isolated using standard techniques After twice washing the DNA precipitate with 2 vols. of $95 \%$ ethanol and vacuum-drying the pellet, the DNA was dissolved in $10 \mathrm{mM}$ Tris buffer ( $\mathrm{pH} 74$ ) and digested with DNAse I, phosphodıesterase, alkaline phosphatase and thymıdine phosphorylase (total volume $01 \mathrm{ml}$ ). The hydrolysis was quenched with 3 vols of saturated ammonium sulfate, the precipitate centrifuged and the supernatant containing the hydrolysed base mixture assayed for its thymine and BU content

To glass tubes ( $15 \mathrm{ml}$ capacity) were added $0.1 \mathrm{ml}$ DNA hydrolysate, $03 \mathrm{ml}$ saturated ammonium sulfate solution (if not already added to quench the enzymatic hydrolysis), $01 \mathrm{ml}$ of $01 M$ ammonium phosphate buffer ( $\mathrm{pH} 67$ ), $0010 \mathrm{ml}$ CU internal standard solution ( $1000 \mathrm{ng} \mathrm{CU}), 0010 \mathrm{ml}$ IU internal standard solution (500 $\mathrm{ng} \mathrm{IU}$ ) and $4.0 \mathrm{ml}$ ethyl acetate. The tubes were tightly capped and shaken for $15 \mathrm{~min}$ at room temperature. After centrifugation (room temperature) for $10 \mathrm{~min}$ at $1200 \mathrm{~g}$, the ethyl acetate phase was transferred to clean glass tubes and the ethyl acetate extraction was repeated. The combined organic ex tracts were concentrated to approximately $05 \mathrm{ml}$ by evaporation in a heated vacuum centrifuge and then transferred to $30 \mathrm{ml}$ capacity conical-bottomed reaction vials. The final evaporation to dryness was anded by a stream of arr and heating to $45^{\circ} \mathrm{C}$ To each sample were added 0.040 $\mathrm{ml} \mathrm{BSTFA}$ and the vials were sealed and heated to $85^{\circ} \mathrm{C}$ for $1 \mathrm{~h}$. Up to $3 \mu \mathrm{l}$ of the reaction mixture were injected for GC-MS-SIM analyisis

\section{Standard callbration curve}

Calibration samples $(0.10 \mathrm{ml}$ distllled water) were spiked in duplicate with the appropriate volumes of thymine and BU standard solutions to concentrations ranging from 0 to $2000 \mathrm{ng}$ per $0.10 \mathrm{ml}$ thymine and from 0 to $52 \mathrm{ng}$ per $0.10 \mathrm{ml} \mathrm{BU}$, and subjected to the sample preparation procedure described above. Calibration curve samples were run with each set of experimental samples.

\section{Calculations}

Calibration curves were constructed by plotting the ratio of the peak area of thymine and BU to that of therr respective internal standards (CU and IU) as a 
function of the sample thymine or BU content. The best-fit straight line was determined using the method of least squares. The thymine and BU concentrations of unknown samples were calculated from the least-squares regression line of the calibration curve

\section{RESULTS AND DISCUSSION}

Under the described conditions, the retention times of the bis(trnmethylsilyl) (bis-TMS) derivatives of thymine, CU, BU and IU were 6.77, 7 34, 801 and $8.82 \mathrm{~min}$, respectively Fig. 1 shows the total-1on chromatographic (TIC) profile of a mixture of nucleic acld bases and 5-halouracils derivatized with BSTFA. Complete resolution of all peaks has been achieved Fig. 2 depicts the mass spectra of the bis-TMS denvatives of thymine and its internal standard, CU. Fig 3 depicts the mass spectra of the bis-TMS derivatives of BU and its internal standard, IU. As shown in these figures, the EI mass spectra of the bisTMS derivatives display the typical fragmentation pattern a small but significant molecular ion $(\mathrm{M})^{+}$peak, the base peaks at $(\mathrm{M}-15)^{+}$representing loss of a methyl group, and the characteristic TMS fragments at $m / z 73$ and 147 [10, 11].

To achieve maximum sensitivity in BU quantitation, we monitored in the SIM mode $m / z$ at 319 and 321 , the isotopic (and base) peaks of the $(M-15)^{+}$ complex for BU-bis-TMS $\left(\mathrm{M}^{+}=336\right)$. The $(\mathrm{M}+1)^{+}$ions of thymine $(m / z 271)$

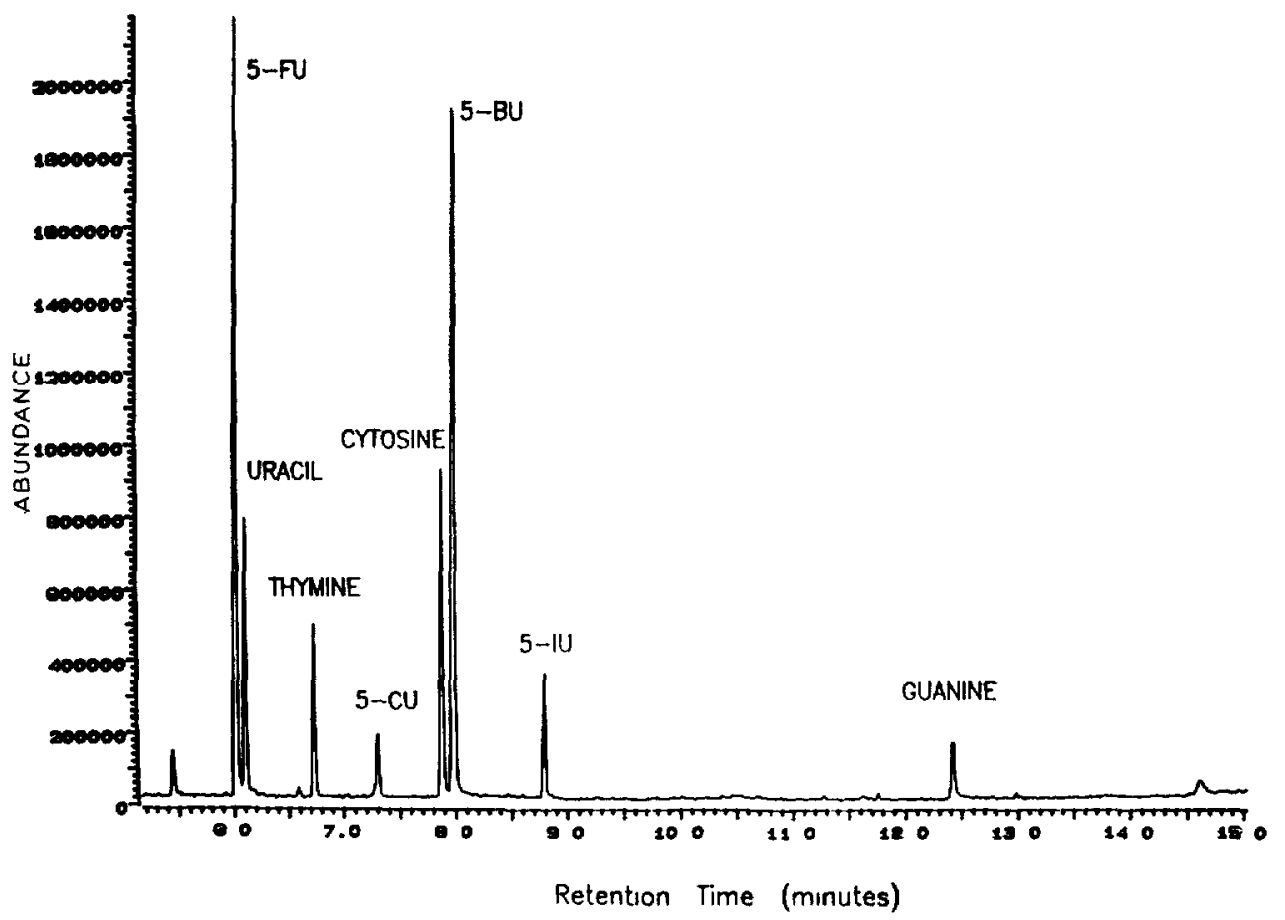

Fig 1. Total-ion chromatogram of a mixture of nucleic acid bases and 5-halouracils denvatized with BSTF A GC-MS conditions were as described in Experimental MS in scan mode, $70-500(m / z)$, electron-impact ionization 


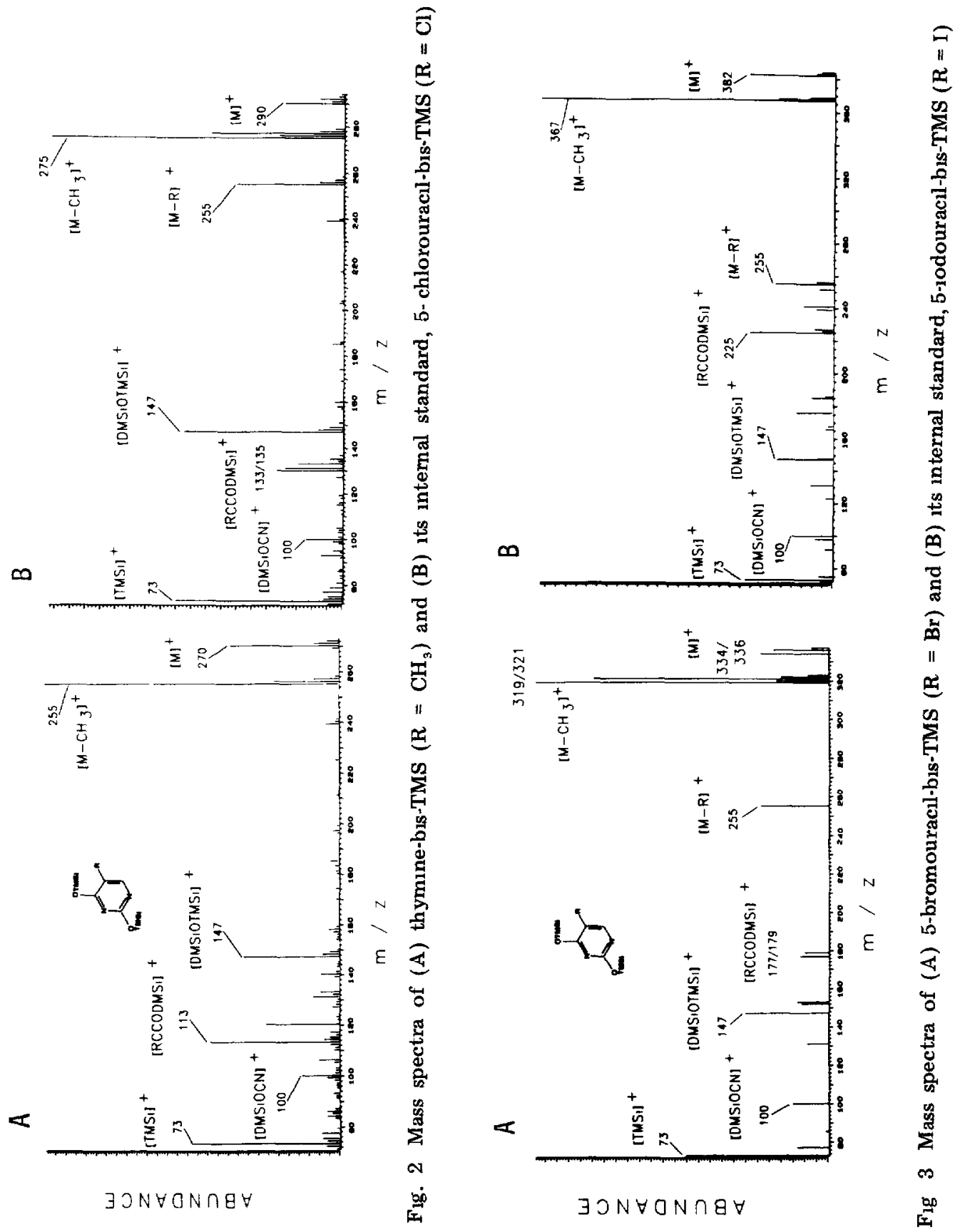


and its internal standard, $\mathrm{CU},(\mathrm{m} / \mathrm{z} 276$, see $\mathrm{Fig}$. 2) were monitored to purposely decrease the thymine assay component peak areas to levels in the range of those elicited by $\mathrm{BU}$ and $\mathrm{IU}$. This results in an increase in the upper linear range for thymine quantitation and allows the simultaneous determination of thymine and BU in a single injection.

The validity of the assay procedure was established through careful study of the linearity of response, reproducibility, accuracy and precision The peak-area ratios (thymine/CU and $\mathrm{BU} / \mathrm{IU}$ ) were directly proportional to the thymine and BU concentrations over a range of $100-2000 \mathrm{ng} / \mathrm{ml}$ and $1.3-52 \mathrm{ng} / \mathrm{ml}$, respec-

\section{TABLE I}

THYMINE CONTENT OF SEEDED CONTROL SAMPLES ( $01 \mathrm{ml}$ ) ASSAYED DURING A THREE-DAY PERIOD

\begin{tabular}{lrrr}
\hline Day & \multicolumn{2}{l}{ Content found (ng) } \\
\cline { 2 - 4 } & $\begin{array}{l}200 \mathrm{ng} \\
\text { Seeded }\end{array}$ & $\begin{array}{r}1000 \mathrm{ng} \\
\text { Seeded }\end{array}$ & $\begin{array}{c}1500 \mathrm{ng} \\
\text { Seeded }\end{array}$ \\
\hline 1 & 2345 & 8811 & 16734 \\
& 2165 & 10527 & 15906 \\
2 & 2365 & 11066 & 15357 \\
& 2064 & 10130 & 14962 \\
& 2206 & 10130 & 15202 \\
& 2228 & 9551 & 15191 \\
& 1970 & 9836 & 15525 \\
& 1952 & 10134 & 14998 \\
Mean \pm S D & 2040 & 9204 & 14506 \\
Coefficient of variation (\%) & $2148 \pm 152$ & $9932 \pm 680$ & $15376 \pm 641$ \\
Difference from theoretical value (\%) & 774 & 68 & 42 \\
\hline
\end{tabular}

TABLE II

5-BROMOURACIL CONTENT OF SEEDED CONTROL SAMPLES $(01 \mathrm{ml})$ ASSAYED DURING A THREE-DAY PERIOD

\begin{tabular}{|c|c|c|c|}
\hline \multirow[t]{2}{*}{ Day } & \multicolumn{3}{|c|}{ Content found (ng) } \\
\hline & $\begin{array}{l}26 \mathrm{ng} \\
\text { Seeded }\end{array}$ & $\begin{array}{l}104 \mathrm{ng} \\
\text { Seeded }\end{array}$ & $\begin{array}{l}208 \mathrm{ng} \\
\text { Seeded }\end{array}$ \\
\hline \multirow[t]{3}{*}{1} & 271 & 973 & 2263 \\
\hline & 285 & 1254 & 1964 \\
\hline & 275 & 1038 & 1996 \\
\hline \multirow[t]{3}{*}{2} & 259 & 985 & 1826 \\
\hline & 256 & 912 & 1913 \\
\hline & 279 & 962 & 1928 \\
\hline \multirow[t]{3}{*}{3} & 277 & 1111 & 2051 \\
\hline & 277 & 1113 & 2024 \\
\hline & 298 & 1121 & 1928 \\
\hline Mean \pm S D & $275 \pm 013$ & $1052 \pm 107$ & $1988 \pm 1.23$ \\
\hline Coefficient of variation $(\%)$ & 46 & 102 & 62 \\
\hline Difference from theoretical value (\%) & +58 & +12 & -44 \\
\hline
\end{tabular}


tively. The best-fit lines were obtained using linear regression analyses. The results of the regression analyses for thymine and BU were $y=0.000570 x+000283$ $(r=09995)$ and $y=000377 x+0.000569(r=0.9977)$, respectively.

The accuracy and precison of the method were assessed by seeding water at thymine and BU concentrations of 200,1000 and $1500 \mathrm{ng}$ per $0.10 \mathrm{ml}$ thymine and 2.6, 10.4 and $20.8 \mathrm{ng}$ per $0.10 \mathrm{ml}$ BU Triplicate quality-control samples at each concentration were assayed on each of three consecutive days. Tables I and II give the results of this experiment. The precision of the assay was found to have coefficients of variation ( $\mathrm{C} \mathrm{V}$.) ranging from 4.2 to $7.1 \%$ and from 4.6 to $102 \%$ for thymine and $\mathrm{BU}$, respectively The concentration means for the seeded control samples were found to be within -0.7 to $7.4 \%$ and -4.4 to $5.8 \%$ of the theoretical values for thymine and $\mathrm{BU}$, respectively.

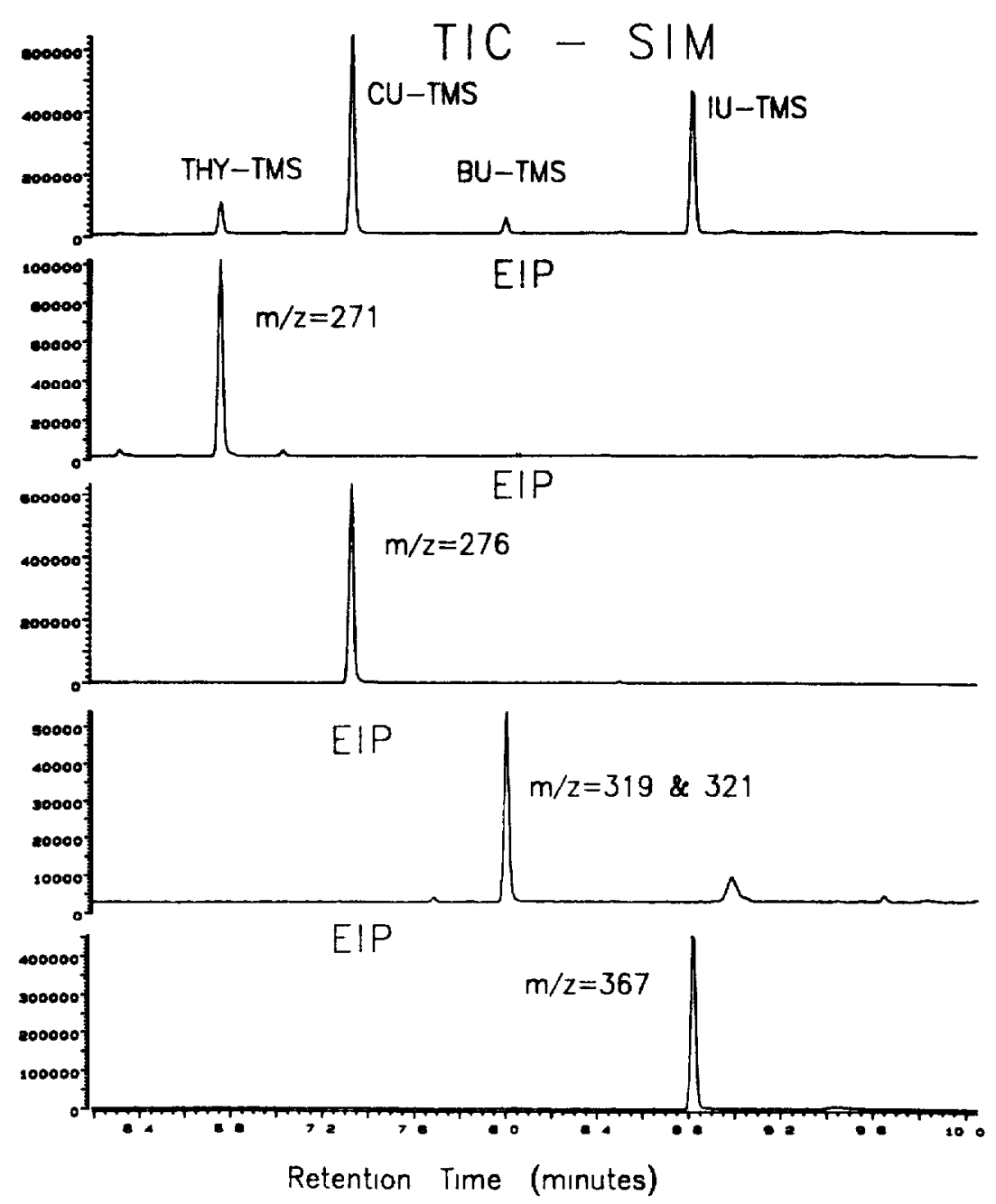

Fig 4 Total-1on chromatogram and the extracted-ion profiles (EIP) of a sample prepared from DNA isolated from V79 cells in culture exposed to $10 \mu M$ BUDR for $40 \mathrm{~h}$ 
TABLE III

SUBSTITUTION OF CELLULAR DNA THYMINE BY 5-BROMOURACIL IN V79 CELLS EXPOSED TO MEDIUM CONTAINING BUDR

\begin{tabular}{|c|c|c|c|c|c|}
\hline \multirow{3}{*}{$\begin{array}{l}\text { BUDR } \\
\text { exposure } \\
(\mu M)\end{array}$} & \multicolumn{4}{|c|}{ Content } & \multirow{3}{*}{$\begin{array}{l}\text { Substitution } \\
(\%)\end{array}$} \\
\hline & \multicolumn{2}{|c|}{ Thymine } & \multicolumn{2}{|c|}{ 5-Bromouracil } & \\
\hline & $\mathrm{ng}$ & nmol & ng & nmol & \\
\hline $\begin{array}{lll}0 & 00 \\
0 & 03 \\
0 & 10 \\
0 & 30 \\
1 & 00\end{array}$ & $\begin{array}{l}5604 \\
3753 \\
287.7 \\
3643 \\
3106\end{array}$ & $\begin{array}{l}445 \\
298 \\
228 \\
289 \\
247\end{array}$ & $\begin{array}{rl}0 & 0 \\
6 & 01 \\
27 & 5 \\
57 & 2 \\
185 & 4\end{array}$ & $\begin{array}{ll}0 & 000 \\
0 & 031 \\
0 & 144 \\
0 & 299 \\
0 & 971\end{array}$ & $\begin{array}{rr}0 & 00 \\
1 & 03 \\
5 & 94 \\
9 & 38 \\
28 & 22\end{array}$ \\
\hline
\end{tabular}

Application of the method developed is demonstrated in Fig. 4 and Table III. V79 cells in culture were exposed for a period of $40 \mathrm{~h}$ to medium containing $0,0.03,0.10,0.30$ or $1.0 \mu M$ BUDR. After isolation and hydrolysis of the DNA, the samples were analysed as to their thymine and BU content Fig. 4 illustrates the TIC profile and the extracted-ion profiles (EIP) of the sample prepared from DNA isolated from cells exposed to $10 \mu M$ BUDR No interfering peaks were seen in the DNA hydrolysate preparations. Table III summarizes the results of this experiment. As shown in Table III, exposure to BUDR under the expernmental conditions resulted in increasing percent thymidine substitution by the 5-halo-2'-deoxyunidine, BUDR, ultimately reaching $28 \%$.

Since the average DNA content of a diploid mammalian cell is on the order of $6 \mu \mathrm{g}$ per $10^{6}$ cells, with a guanine/cytosine content of about $40 \%$ [12], quantitative recovery of thymine from the hydrolyzed DNA of $10^{5}$ cells should yield $695 \mathrm{ng}(055 \mathrm{nmol})$. In experiments not shown here were recovered $44.4 \mathrm{ng}(0.35 \mathrm{nmol})$ thymine from $10^{5}$ V79 cells. Based on a minimum detectable level of $\mathrm{BU}$ of $1.2 \mathrm{ng}(0.006 \mathrm{nmol})$ we should, therefore, be able to measure replacement on the order of $2 \%$ using $10^{5}$ V79 cells.

As previously mentioned, the GC-MS-SIM method described here can quantitatively determine the amount of DNA thymıne replacement by BU in as few as $10^{5}$ cells. In confirmation of prior studies, we have found, using external beam radiotherapy, that the enhancement factor for radiosensitivity in the $\nu 79$ cell line is a drect function of the percent thymine replacement by BU. This procedure can also be used in conjunction with the monoclonal antibody/fluorescence actıvated cell sortıng (FACS) techniques to correlate the FACS distributions with DNA thymme replacement by BU. And finally, in as much as $10^{5}$ cells can be readily obtained by needle bropsy techniques, this method should be applicable to multiple sampling in animal and patient studies. This will allow the correlation of routes and schedules of BUDR administration with appropriate target effect, 1.e BU replacement of thymine in tumor and normal tissues (such as bone marrow). 


\section{ACKNOWLEDGEMENT}

Th1s work was supported in part by NIH Grant No CA33825.

\section{REFERENCES}

1 B Djordjevic and W Szybalsk1, J Exp Med, 112 (1960) 509

2 E H Simmon, Exp Cell Res Suppl , 9 (1963) 263

3 G H Thomas, M A Maloney and J E Cleaver, Radiat Res, 91 (1982) 145

4 W Szybalskı, Cancer Chemother Rep, 58 (1974) 539

5 T Kinsella, J B Mitchell and A Russo, Int J Radiat Oncol Bıol Phys, 10 (1984) 1399

6 T Kinsella, J B Mitchell and A Russo, J Clin Oncol , 2 (1984) 1144

7 G P Raaphorst, J A Vadasz and E I Azzam, Radıat Res, 98 (1984) 167

8 F Dolbeare, H Gratzner, M G Pallovicin and J W Gray, Proc Natl Acad Sci U S A, $80(1983) 5573$

9 G Morstyn, S M Hsu and T Kinsella, J Clin Invest, 72 (1983) 1844

10 C Finn and W Sadee, Cancer Chemother Rep, 59 (1975) 279

11 D B Lakıngs, R H Adamson and R B Diasio, J Chromatogr, 146 (1978) 512

12 J N Davidson, The Biochemistry of Nucleic Acids, Academic Press, New York, 7th ed, 1975 